\title{
Analisa Berpikir Statistis Siswa Berdasarkan Gaya kognitif Visualizer-Verbalizer untuk Kasus Statistik
}

\author{
Abdul Syukur, Yusra Yunus, Sirajuddin
}

How to cite : Syukur, A., Yunus, Y, \& Sirajuddin, 2021. Analisa Berpikir Statistis Siswa Berdasarkan Gaya kognitif Visualizer-Verbalizer untuk Kasus Statistik. Kognitif: Jurnal Riset HOTS Pendidikan Matematika. 1(1). 1-9. https://doi.org/ 10.51574//ognitif.v1i1.4

To link to this article : https://doi.org/ 10.51574/kognitif.v1i1.4

Opened Access Article

Published Online on 1 Juni 2021

牙 Submit your paper to this journal 


\title{
Analisa Berpikir Statistis Siswa Berdasarkan Gaya kognitif Visualizer- Verbalizer untuk Kasus Statistik
}

\author{
Abdul Syukur ${ }^{1}$, Yusra Yunus ${ }^{2}$, Sirajuddin $^{3 *}$ \\ ${ }^{1}$ Sekolah Dasar Negeri 84 Mangarabombang \\ ${ }^{2}$ Sekolah Menengah Atas Negeri 1 Sinjai Utara \\ ${ }^{3}$ Pendidikan Guru Sekolah Dasar, Fakultas Keguruan dan Ilmu Pendidikan, Universitas Muhammadiyah \\ Makassar
}

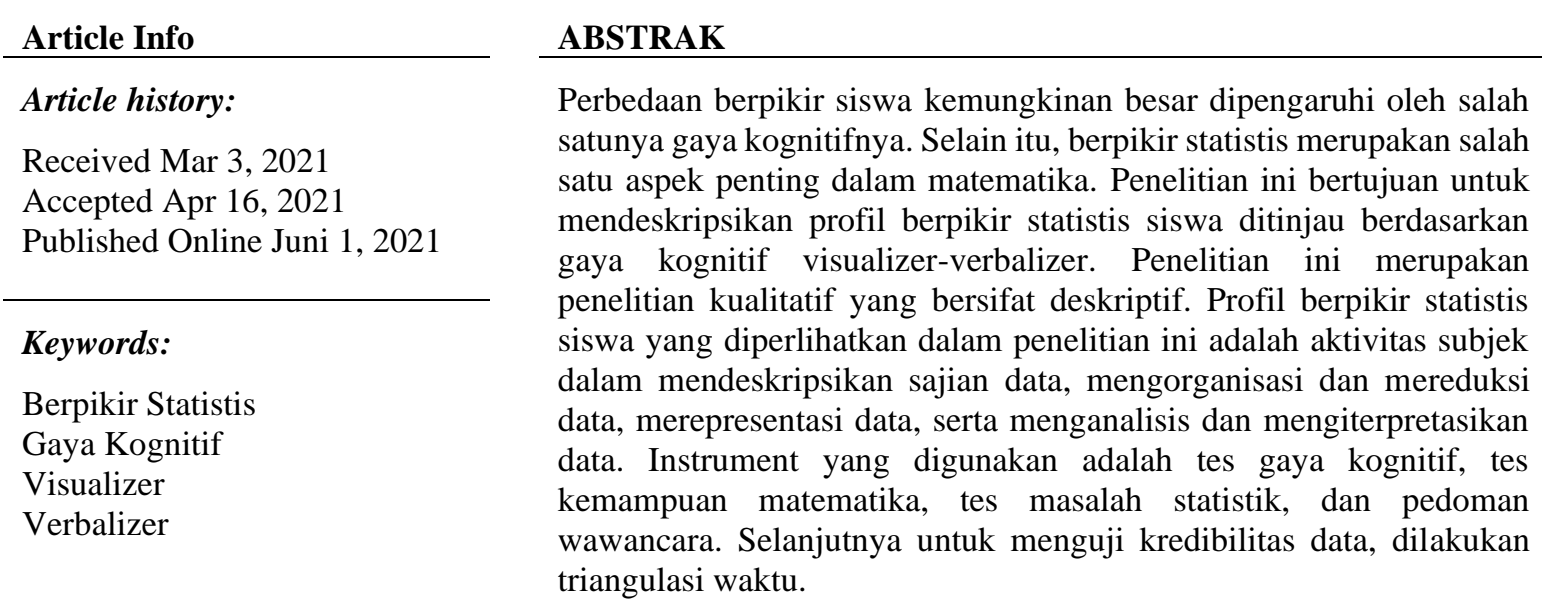

\section{Corresponding Author:}

Sirajuddin,

Pendidikan Guru Sekolah Dasar,

Fakultas Keguruan dan Ilmu Pendidikan,

Universitas Muhammadiyah Makassar

Email: sirajuddin@unismuh.ac.id

\section{Pendahuluan}

Salah satu ilmu pengetahuan yang dipelajari dalam matematika adalah statistika. Statistika merupakan materi yang penting untuk diajarkan disekolah, sesuai yang termuat dalam kurikulum yang termuat dalam Permendikbud tahun 2013 bahwa salah satu materi yang wajib diajarkan pada siswa adalah statistika. Untuk mempelajari atau mengetahui statistika, maka diperlukan suatu proses berpikir, dengan mengetahui proses berpikir siswa maka guru bisa mengenali karakteristik siswa tersebut sehingga dapat dirancang sebuah strategi pembelajaran yang efektif dalam suatu pengajaran di kelas, maka peneliti menganggap penting untuk meneliti profil berpikir siswa dalam hal ini berpikir statistis siswa. Davies et al (2011) 
menyatakan bahwa berpikir untuk mendapatkan kesimpulan dari data atau bukti-bukti merupakan berpikir statistis. Berpikir statistis melibatkan pemahaman tentang sifat sampling, bagaimana membuat kesimpulan dari sampel populasi (Kuntze et al., 2017). Dalam hal ini, berpikir statistis menggambarkan proses yang terlibat dalam praktek penyelidikan statistis berbasis data untuk mendapatkan kesimpulan.

Berpikir statistik digunakan untuk menjelaskan proses berpikir yang berbagai sifat tentang variasi, melakukan identifikasi, mengkarakterisasi, mengkuantifikasi, mengkontrol, dan mereduksi untuk memberikan kesempatan yang khas untuk perbaikan. “... setiap usaha dibentuk koleksi proses yang saling terhubung yang masuk, variabel kontrol, dan output adalah subjek terhadap variasi (English \& Watson, 2016). Ini mengarah pada kesimpulan bahwa berpikir statistis harus digunakan secara rutin pada semua level pengorganisasian. Jadi berpikir statistis harus digunakan secara rutin pada semua level pengorganisasian, misalnya pada saat melakukan identifikasi, karakteristisasi, kualifikasi dan pengendalian variasi. Zahner \& Corter (2010) menyatakan bahwa berpikir statistis (statistical thinking) memiliki 4 tahap, yaitu: (1) Mendeskripsikan sajian data (Describing Data Displays); (2) Mengorganisasi dan mereduksi data((Organizing and Reducing Data)); (3) Merepresentasi data (Representing Data); dan (4) Menganalisis dan mengiterpretasikan data (Analyzing and Interpreting Data. Elemen kunci dalam mendeskripsikan data adalah sebagai berikut: (a) Membaca tampilan data, (b) Menunjukkan pemahaman tentang konveksi unsur-unsur grafik (misalnya, judul, sumbu tabel), (c) Memiliki pemahaman ketika diberikan tampilan berbeda untuk data yang sama, dan (d) Mengevaluasi tampilan yang berbeda dari data yang sama. Adapun indikator dari berpikir statistis yang kami gunakan dalam artikel ini ditunjukkan pada Tabel 1.

Tabel 1. Indikator Berpikir Statistis

\begin{tabular}{|l|l|}
\hline Berpikir Statistis & \multicolumn{1}{|c|}{ Indikator } \\
\hline $\begin{array}{l}\text { Mendeskripsikan } \\
\text { sajian data }\end{array}$ & $\begin{array}{l}\text { - Menunjukkan keistimewaan (kekhasan) sajian data } \\
\text { - Mengenali tampilan data yang berbeda dalam data yang sama } \\
\text { - Mengevaluasi keefektifan penyajian data }\end{array}$ \\
\hline $\begin{array}{l}\text { Mengorganisasi } \\
\text { dan mereduksi } \\
\text { data }\end{array}$ & $\begin{array}{l}\text { - Mengelompokkan data } \\
\text { - Menyajikan ukuran pemusatan data }\end{array}$ \\
$\begin{array}{l}\text { Merepresentasi } \\
\text { data }\end{array}$ & $\begin{array}{l}\text { - Mengkonstruk sajian data dari kumpulan data atau sajian data } \\
\text { yang diberikan }\end{array}$ \\
\hline $\begin{array}{l}\text { Menganalisis dan } \\
\text { mengiterpretasika } \\
\text { n data }\end{array}$ & $\begin{array}{l}\text { - Mengkonstruk sebuah tampilan data berdasarkan tampilan } \\
\text { - Membandingkan antar dalam sajian data atau kumpulan data } \\
\text { - Membandingkan antar kumpulan data atau sajian data }\end{array}$ \\
\hline
\end{tabular}

Selanjutnya, untuk menelusuri berpikir statistis, kami menemukan bahwa pemikir statistis dipengaruhi oleh bagaimana siswa tersebut memperoleh, menyimpan, dan menggunakan informasi yang diterimanya atau disebut sebagai gaya kognitif. Gaya kognitif berkaitan dengan kebiasaan individu menggunakan alat inderanya, yang dapat dibedakan menjadi dua kelompok, yaitu visualizer dan verbalizer (Haciomeroglu, 2016; Pitta-Pantazi \& Christou, 2009; Stylianides \& Stylianides, 2009). Dimana sistem kognitif dibagi menjadi dua komponen, yaitu sistem visual dan sistem verbal (lisan). Siswa visualizer cenderung memiliki kemampuan melihat sehingga memiliki kebiasaan menerima dan memproses informasi dalam bentuk gambar, sedangkan siswa verbalizer cenderung memiliki kemampuan mendengar sehingga memiliki kebiasaan menggunakan teks dalam menerima dan memproses informasi. Selanjutnya, individu yang memiliki gaya kognitif visualize cenderung lebih banyak dalam 
gambar, lebih lancar dengan ilustrasi dan terjemahan, serta memahami dan menyukai permainan yang lebih visual, seperti teka-teki. Seseorang yang bergaya kognitif visualizer lebih menyukai grafik, senang dalam menggambar, dan cenderung melihat-lihat situasi di lingkungan sekitarnya. Oleh karena itu, individu yang memiliki gaya kognitif verbalizer lebih cenderung mengatakan dan akan lebih memilih untuk berkomunikasi kepada seseorang dengan menunjukkan bagaimana mereka melakukannya. Seseorang yang bergaya kognitif verbalizer lebih menyukai bacaan, senang dalam menulis, dan cenderung mendengarkan pembicaraan di lingkungan sekitarnya. sehingga kemungkinan pada kedua siswa dengan gaya kognitif yang berbeda tesebut dalam berpikir ststistis yaitu dalam merepresentasikan sajian data, mengorganisasi dan mereduksi data, merepresentasikan data, serta menganalisis dan mengiterpertasikan data juga berbeda, karena dipengaruhi oleh gaya kognitifnya. siswa dengan gaya kognitif visualizer cendrung menggunakan gambar sedangkan siswa dengan gaya kognitif verbalizer cendrung menggunakan teks, maka hubungan antara gaya kognitif dengan berpikir statistis siswa yaitu profil berpikis statistis siswa tergantung pada gaya kognitif yang dimiliki siswa tersebut, dalam hal ini gaya kognitif visualizer-verbalizer

Adapun pertanyaan penelitian yang kami kembangkan yakni

"Bagaimana analisa Analisa Berpikir Statistis Siswa Berdasarkan Gaya

kognitif Visualizer-Verbalizer untuk Kasus Statistik?"

\section{Metode}

Penelitian ini termasuk jenis penelitian deskriptif dengan menggunakan pendekatan kualitatif karena peneliti ingin mendeskripsikan profil berpikir statistis siswa SMP berdasarkan gaya kognitif visualizer dan verbalizer. Menurut Miles et al (2014) penelitian dengan pendekatan kualitatif adalah penelitian yang digunakan untuk memahami secara holistik fenomena yang dialami oleh subjek penelitian pada suatu konteks khusus yang alamiah dengan cara mendeskripsikannya dalam bentuk kata-kata dan bahasa dengan metode alamiah. Data kualitatif pada penelitian ini adalah hasil jawaban siswa. Selain itu, dilaksanakan pula wawancara yang dilakukan peneliti terhadap subjek penelitian agar mendeskripsikan secara detail mengenai berpikir statistis siswa.

\section{Subjek}

Penelitian ini dilakukan pada siswa di tingkat menengah (SMP). Adapun penentuan subjek dalam penelitian ini adalah siswa yang terdiri satu siswa dengan gaya kognitif visualizer dan satu siswa dengan gaya kognitif verbalizer. Penggolongan siswa dalam dua kategori tersebut sesuai dengan hasil tes kemampuan matematika relatif sama dan bisa berkomunikasi dengan baik serta mau diwawancarai. Untuk menentukan subjek penelitian yang memiliki gaya kognitif visualizer dan verbalizer, maka peneliti melakukan pemilihan subjek dengan menggunakan instrumen tes penggolongan gaya kognitif (TGK) (Haciomeroglu \& LaVenia, 2017) di kelas yang disarankan oeh guru mata pelajaran matematika di sekolah. Kemudian siswa dikelompokkan sesuai dengan gaya kognitifnya masing-masing. Selanjutnya, Memberikan tes kemampuan awal matematika pada siswa. Dalam penelitian ini subjek penelitian dikatakan memiliki kemampuan matematika yang setara, jika nilai tes kemampuan awal matematika diantara subjek-subjek tersebut memiliki selisih $\leq 10$ untuk rentang nilai 0 100. Terakhir, kami memilih siswa yang bisa berkomunikasi dengan baik. Informasi ini dapat diperoleh dari diskusi dengan guru siswa yang bersangkutan 


\section{Instrumen Pengumpulan Data}

Dalam penelitian ini, instrument utama dalam pengumpulan data adalah peneliti sendiri. Hal ini dikarenakan hanya penelitilah yang berhubungan langsung dengan subjek penelitian, dan hanya peneliti yang mampu memahami kaitan kenyataan-kenyataan di lapangan melalui observasi dan wawancara, serta tidak dapat diwakilkan kepada orang lain. Kedudukan peneliti sebagai instrument utama berfungsi untuk menetapkan fokus penelitian, memilih subjek penelitian, melakukan pengumpulan data, menganalisis data, menafsirkan data, dan membuat kesimpulan (Creswell, 2012). Selanjutnya, kami mengembangkan instrumen pendukung, yakni pertama, Tes Penggolongan Gaya Kognitif. Tes ini bertujuan untuk mengelompokkan gaya kognitif mahasiswa visualizer dan verbalizer. Kedua, Tes kemampuan matematika, berupa tes kemampuan awal matematika pada siswa. Kami menggunakan soal Ujian Nasioanal tingkat menengah yang dimodifikasi menjadi soal uraian sebanyak 10 butir soal. Alasan memilih soal uraian adalah untuk lebih mengetahui kemampuan matematika subjek, karena dengan soal uraian proses penyelesaian soal lebih terlihat. Sebelum soal diberikan kepada calon subjek penelitian, terlebih dahulu dikonsultasikan kepada pembimbing dan divalidasi ahli. Setelah dilakukan revisi dan disetujui pembimbing serta validator maka soal tes kemampuan matematika dapat digunakan. Ketiga, Tes Masalah Statistis (TMS), Soal masalah statistis yang digunakan dalam penelitian ini berisi sosl-soal statistika non-rutin yang dirancang untuk mengetahui profil berpikir statistis siswa.

\section{Pengumpulan Data}

Teknik pengumpulan data pada penelitian ini adalah dengan pemberian tes masalah statistika dan wawancara. Subjek diminta menyelesaikan tes dalam batas waktu yang telah ditetapkan. Selanjutnya peneliti (dengan dibantu oleh guru di sekolah tersebut) mewawancarai subjek penelitian secara lebih mendalam berdasarkan respon siswa terhadap tes yang diberikan. Wawancara juga digunakan untuk memperoleh informasi yang mungkin tidak diperoleh saat tes tertulis, karena tidak semua yang dipikirkan siswa mampu dituliskan. Hal ini mungkin dapat terungkap ketika wawancara.

Untuk menjamin keabsahan data dalam penelitian ini, peneliti melakukan triangulasi waktu yaitu melakukan pengecekan dengan tugas tertulis dan wawancara, dalam waktu atau situasi yang berbeda. Pada penelitian ini, dilakukan pengumpulan data sebanyak 2 (dua) kali. Jarak antara pengumpulan data pertama dan data kedua adalah minimal 2 (dua) minggu. Data yang diperoleh kemudian dibandingkan. Data dikatakan valid jika ada konsistensi atau kesamaan pandangan antara data pertama dan data kedua. Jika data yang diperoleh belum valid, maka dilakukan pengumpulan data berulang kali sampai data yang diperoleh valid. Selanjutnya data yang valid digunakan dalam penelitian ini.

\section{Analisis Data}

Data hasil tes masalah statistika dan hasil wawancara kemudian dianalisis dengan pendekatan kualitatif. Analisis data dalam penelitian ini mengacu pada tahapan analisis data kualitatif. Pertama, tahap reduksi data, Data yang telah diperoleh dari tes masalah statistika dan wawancara kemudian direduksi. Reduksi data ini dimaksudkan untuk menyeleksi dan memfokuskan data-data yang telah diperoleh di lapangan. Dari proses reduksi ini, data-data dipilih, disederhanakan, kemudian dikelompokkan dengan data-data yang sesuai dengan kebutuhan untuk menjawab pertanyaan penelitian. Data hasil wawancara dituangkan secara tertulis dengan cara sebagai berikut: (1) Mentranskripkan ucapan yang dituturkan subjek selama wawancara; (2) Mereduksi data dengan membuat rangkuman inti, dengan membandingkan hasil transkrip dengan menggunakan recorder selama wawancara berlangsung. Kedua, Tahap 
penyajian data, Penyajian data dalam penelitian ini meliputi kegiatan pengelompokan dan identifikasi data yang dilakukan dengan menuliskan kumpulan data yang teroganisir dan terkategori, sehingga memungkinkan untuk menarik kesimpulan. Adapun tujuan dari penyajian data adalah untuk mempermudah dalam penarikan kesimpulan. Ketiga, Tahap penarikan kesimpulan, Penarikan kesimpulan didasarkan pada hasil analisis terhadap data yang telah dipaparkan dan dibahas secara jelas berdasarkan fase-fase yang telah ditetapkan. Selanjutnya penarikan kesimpulan dari data tersebut tentang profil berpikir statistis siswa berdasarkan gaya kognitif visualizer-verbalizer

\section{Hasil Penelitian}

\section{Subjek gaya kognitif verbalizer}

Berdasarkan analisis hasil penelitian yang telah dilakukan terhadap subjek gaya kognitif visualizer, maka peneliti mengidentifikasi bahwa deskripsi berpikir statistis subjek visualizer adalah sebagai berikut:

\section{Mendeskripsikan Sajian Data}

Dalam mendeskripsikan sajian data, terdapat tiga indikator yang dilakukan oleh subjek yaitu pertama, menunjukkan keistimewaan data yang dilakukan pada saat menemukan hal yang menarik dalam sajian data yaitu dengan membandingkan besar sudut juring dalam diagram lingkran yaitu membandingkan sudut paling besar dengan sudut yang paling kecil. Kedua, mengenali tampilan berbeda dalam data yang sama yaitu subjek membandingkan antara diagram lingkaran dengan diagram batang, dengan menganggap bahwa kedua tampilan diagram tersebut sama tetapi data yangberbeda. Ketiga, mengevaluasi keefektifan data yaitu subjek menganggap bahwa diagram yang paling efektif dalam penyajian data adalah diagram lingkaran.

\section{Mengorganisasi dan Mereduksi Data}

Dalam mengorganisasi dan mereduksi data, ada dua indicator yang dilakukan subjek yaitu pertama, mengelompokkan data, pada saat menentukan median yaitu subjek mengurutkan data dari data terkecil kedata terbeasar. Kemudian subjek tersebut menghitung urutan data dari urutan pertama sampai urutan ke dua belas. Kemudian memisahkan antara urutan 1 sampai 6 dengan urutan 7 sampai 8, dan urutan 9 sampai dua belas. Dengan pemisahan tersebut, subjek telah melakukan pengelompokan data.

Kedua, menyajikan ukuran pemusatan data dengan menentukan modus, median, ratarata yaitu pertama-tama subjek menentukan modus dengan cara terlebih dahulu mengartikan modus sebagai data yang paling banyak muncul. Kemudian melihat angka yang paling banyak berulang, selanjutnya bilangan yang paling banyak berulang tersebut sebagai modus. Kemudian dalam menentukan median, telebih dahulu subjek mengurutkan data dari data terkecil kedata terbesar dengan melihat digram lingkaran dan table. Kemudian milih data yang paling tengah, dengan cara urutan ke-7 dan ke-8 dijumlahkan lalu dibagi dengan 2. Selanjutnya menentukan rata-rata dengan cara subjek mengartikan rata-rata sebagai jumlah data dibagi banyaknya data, setelah itu subjek menentukan jumlah data dengan cara menghitung jumlah keseluruhan siswa yang hadir pada saat pemberian angket.. Kemudian menentukan banyaknya data, dengan cara menghitung banyak jenisfitur pada data. Setelah menemukan jumlah data dan banyaknya data, kumudian jumlah data tersebut dibagi dengan banyaknya data. Maka dari hasil pembagian tersebut itulah sebagi nilai rata-ratanya.

\section{Merepresentasi data}

Dalam merepresentasi data, ada dua indikator yang dilakukan subjek, yaitu mengkonstruk sajian data dari sajian data yang diberikan dengan cara mengkonstruk diagram garis dengan berdasarkan data pada tabel. Subjek mengkonstruk digram garis tersebut, pertama 
subjek melihat data pada table, kemudian membuat garis jumlah data (vertikal) dan garis banyak data (horizontal) dengan membentuk sumbu x,y. menuliskan jumlah peminat pada garis vertical dan menuliskan nama jenis kegiatan maupun nama alat music pada garis horizontal. selanjutnya menghubungkan kedua garis tersebut dengan sebuah titik pada masing-masing jenis kegiatan atupun alat music dengan banyak siswa yang memilih. Selajutnya menghubungkan titik-titik tersebut dengan menarik sebuah garis.

Kedua, mengkonstruk sebuah tampilan data berdasarkan tampilan yang disajikan dengan cara membuat diagram batang dengan berdasarkan diagram lingkaran. Dalam mengkontruk diagram batang hampir sama pada saat membuat diagrm garis, namun yang membedakan hanya pada saat menghungkan kedua garis antara garis horizontal dengan garis vertical, yaitu dihubungkan dengan gambar yang menyerupai batang/balok.

\section{Menganalisis dan Mengiterpretasikan Data}

Dalam menganalisis dan mengiterpretasikan data, ada tiga indicator yang dilakukan subjek, yakni pertama, membandingkan antar dalam sajian data atau kumpulan data yang diberikan, dengan cara membandingkan jumlah siswa dalam sajian data dengan memperhatikan jumlah siswa terbanyak. Kedua, membandingkan antar kumpulan data atau sajian data, dengan cara membandingkan jumlah peminat kegiatan ektrakurikuler sekolah maupun pada jenis alat music antara kelas VII dengan kelas VIII. dengan memperhatikan jenis kegiatan maupun alat musik yang paling banyak diminati oleh siswa. Ketiga, membuat kesimpulan data dengan memperhatikan kegiatan ektrakurikuler maupun alat music yang paling bnyak diminati siswa yaitu pramuka dan gitar yang paling banyak diminati oleh siswa.

\section{Subjek gaya kognitif verbalizer}

Berdasarkan analisis hasil penelitian yang telah dilakukan terhadap subjek gaya kognitif verbalizer, maka peneliti mengidentifikasi bahwa deskripsi berpikir statistis subjek verbaliser dipaparkan sebagai berikut:

\section{Mendeskripsikan Sajian Data}

Dalam mendeskripsikan sajian data, ada tiga indikator yang dilakukan oleh subjek yaitu pertama, menunjukkan keistimewaan data dengan cara menemukan hal yang menarik pada sajian data dengan melihat data yang sama. Kedua, , mengenali tampilan berbeda dalam data yang sama yaitu pada saat subjek membandingkan antara data diagram lingkaran dengan data diagram batang dengan menganggap bahwa kedua tampilan diagram tersebut berbeda namun memilki data yang sama. Ketiga, mengevaluasi keefektifan sajian data yaitu menganggap bahwa diagram garis yang paling efektif dalam penyajian data.

\section{Mengorganisasi dan Mereduksi Data}

Dalam mengorganisasi dan meruduksi data, ada dua indicator yang dilakukan subjek yaitu pertama, mengelompokkan data yaitu mengelompokkan jumlah peminat yang sama banyak. Kedua, menyajikan ukuran pemusatan data dengan menentukan modus, median dana rata-rata. subjek menentukan modus dengan cara melihat jenis kegiatan ektrakurikuler serta jenis alat music yang paling banyak diminati siswa, karena subjek menganggap bahwa modus adalah data yang paling besar atau kegiatan yang paling banyak diminati siswa. Kemudian dalam menentukan median dengan mengurutkan data terlebih dahulu, kemudian di ambil data yang berada pada posisi paling tengah.. selanjutnya menentukan rata-rata, dengan cara jumlah data dibagi dengan banyaknya data. Sebelumnya subjek menentukan jumlah data dengan menghitung total siswa yang berminat maupun yang tidak berminat, setelah itu menentukan banyaknya data dengan cara menghitung jumlah jenis kegiatan ektrakurikuler maupun jenis alat music. Setelah didapatkan totalnya, kemudian subjek membagi jumlah data dibagi dengan banyaknya data sebagi nilai rata-rata.

\section{Merepresentasi Data}

Dalam merepresentasi data, ada dua indikator yang dilakukan subjek, yaitu pertama, mengkonstruk sajian data dari sajian data yang diberikan, yaitu pada saat membuat diagram 
garis dengan berdasarkan data pada tabel, yaitu subjek mengaitkan antara diagram garis yang dibuat dengan data pada diagram lingkaran. Dalam membuat diagram garis tersebut, terlebih dahulu subjek memperhatikan data pada diagram lingkaran, kemudian membuat garis horizontal (banyaknya data) dan garis vertical (jumlah data) yang membentuk x, y. selanjutnya dihubungkan kedua garis tersebut dengan mebuat titik, kemudian titik-titik tersebut dihubungkan dengan menarik garis.

Kedua, mengkonstruk sebuah tampilan data berdasarkan tampilan yang disajikan pada saat mengkonstruk diagram batang dengan berdasarkan data pada data diagram lingkaran. Dalam mengkontruk diagram batang hampir sama mengkonstruk diagram garis, namun yang membedakannya hanya pada saat menghubungkan antara garis horizontal dengan garis vertical yaitu dihubungkan dengan berupa gambar batang/balok.

\section{Menganalisis dan Mengiterpretasikan Data}

Dalam menganalisis dan mengiterpretasikan data, ada tiga indicator yang dilakukan subjek, yakni pertama, membandingkan antar dalam sajian data atau kumpulan data yaitu membandingkan jenis fitur dalam sajian dengan memperhatikan fitur yang paling banyak diminati siswa. Kedua, membandingkan antar kumpulan data atau sajian data dengan membandingkan fitur sajian data dengan memperhatikan fitur data yang paling besar peminatnya dengan yang paling sedikit peminatnya. Ketiga, membuat kesimpulan data yang disajikan dengan menyimpulkan bahwa kegiatan ektrakurikuler dan alat music yang paling banyak dimianti siswa adalah pramuka dan gitar pada kedua sajian tersebut.

\section{Diskusi}

Berdasarkan hasil analisis data, maka dapat disimpulkan bahwa profil berpikir statistis pada subjek dengan gaya kognitif visualizer maupun subjek gaya kognitif verbalizer adalah sebagai berikut:

\section{Subjek gaya kognitif visualizer}

Dalam mendeskripsikan sajian data yaitu pertama, menunjukkan keistimewaan data yaitu pada saat menemukan hal yang menarik dalam sajian data dengan membandingkan sudut juring pada diagram lingkaran. Kedua, mengenali data tampilan berbeda dalam data yang sama yaitu membandingkan antara diagram lingkaran dengan diagram batang dengan menganggap bahwa kedua tampilan diagram tersebut berbeda namun memiliki data yang sama. Ketiga, mengevaluasi keefektifan data dengan menganggap bahwa diagram lingkaran yang paling efektif dalam penyajian data. Dalam mengorganisasi dan mereduksi data yaitu pertama, mengelompokkan data dengan memisahkan data menjadi 3 bagian, dengan pemisahan tersebut, subjek telah melakukan pengelompokan data. Kedua menyajikan ukuran pemusatan data, dengan menentukan modus, median, dan rata-rata

Dalam merepresentasi data yaitu mengkonstruk sajian data dari sekumpulan data yang diberikan dengan cara mengkonstruk diagram garis dengan berdasarkan data pada tabel. Kedua mengkonstruk sebuah tampilan data berdasarkan tampilan yang disajikan dengan cara membuat diagram batang berdasarkan data pada diagram lingkaran. Dalam menganalisis dan mengiterpretasikan data, yaitu pertama, membandingkan antar dalam sajian data atau kumpulan data, dengan membandingkan jumlah nilai data pada setiap fitur pada data dengan memperhatikan jumlah nilai data terbanyak. Kedua, membandingkan antar kumpulan data atau sajian data, dengan cara membandingkan jumlah nilai data pada keseluruhan fitur pada data antar dua sajian data. Ketiga, membuat kesimpulan data dengan menganggap bahwa fitur pramuka dan gitar memiliki nilai data yang paling besar. Hasil ini sejalan dengan temuan Haciomeroglu (2016) tentang pemikiran anak yang dikategorikan sebagai visualizer. 


\section{Subjek gaya kognitif verbalizer}

Dalam mendeskripsikan sajian data, yakni pertama, menunjukkan keistimewaan data dengan cara menemukan hal yang menarik pada sajian data dengan membandingkan fitur data, Kedua, mengenali tampilan berbeda dalam data yang sama dengan membandingkan diagram diagram lingkaran dengan diagram batang dengan menganggap bahwa kedua tampilan diagram tersebut berbeda namun memiliki data yang sama . Ketiga, mengevaluasi keefektifan sajian data dengan menganggap bahwa diagram garis yang paling efektif dalam menyajikan data

Dalam mengorganisasi dan meruduksi, yakni pertama, mengelompokkan data yaitu dengan cara mengelompokkan jumlah siswa yang sama dalam fitur dalam data. Kedua, menyajikan ukuran pemusatan data dengan menentukan modus, median dana rata-rata. Dalam merepresentasi data, yakni pertama, mengkonstruk sajian data dari kumpulan data yang diberikan dengan cara membuat diagram garis berdasarkan data pada tabel. Ketiga, mengkonstruk sebuah tampilan data berdasarkan tampilan yang disajikan dengan cara mengkonstruk diagram batang berdasarkan data pada data diagram lingkaran.

Dalam menganalisis dan mengiterpretasikan data yaitu pertama, membandingkan antar dalam sajian atau kumpulan data yaitu membandingkan jumlah nilai data dalam setiap fitur data, dengan memperhatikan jumlah nilai data paling banyak dan paling sedikit. Kedua, membandingkan antar kumpulan data atau sajian data dengan cara membandingkan jumlah nilai data dalam keseluruhan fitur data antar kedua sajian data. Ketiga, membuat kesimpulan data yang disajikan dengan menyimpulkan bahwa fitur pramuka dan gitar memiliki data paling besar. Temuan ini sejalan dengan Haciomeroglu \& LaVenia (2017) tentang alur berpikir anak yang dikategorikan sebagai verbalizer.

\section{Simpulan}

Dari temuan diperoleh hasil analisa berpikir statistis siswa berdasarkan gaya kognitif visualizer dan verbalizer. Dimana kedua temuan menunjukkan perbedaan yang signifikan ketika menyelesaikan masalah. Dari hasil penelitian dapat diketahui bahwa, profil berpikir statistis siswa berdasarkan gaya kognitif verbalizer kurang memahami tentang menentukan ukuran pemusatan data pada menentukan modus, dalam hal ini siswa tersebut menganggap bahwa data yang paling banyak muncul adalah jenis kegiatan atau alat music yang paling banyak diminati siswa, bukan data yang paling banyak berulang. Oleh karena itu, peneliti menyarankan agar para pendidik memperhatikan perbedaan gaya kognitif siswa dalam pembelajaran, khususnya dalam memahami modus. Adapun keterbatasan pada penelitian ini adalah sebagai berikut: (1) Instrumen yang digunakan, baik tes masalah statistik dan pedoman wawancara, tidak divalidasi oleh ahli berpikir statistis; dan (2) Peneliti masih terbatas dengan pertanyaan untuk menggali informasi yang ditulis siswa.

\section{Konflik Kepentingan}

Penulis menyatakan tidak ada konflik kepentingan

\section{Referensi}

Creswell, J. W. (2012). Educational research: Planning, conducting, and evaluating quantitative and qualitative research. In Educational Research (Vol. 4). https://doi.org/10.1017/CBO9781107415324.004

Davies, B., Alcock, L., \& Jones, I. (2011). What do mathematicians mean by proof ? A comparative-judgement study of students ' and mathematicians ' views. Journal of Mathematical Behavior, 61(December 2020), 1- 
24. https://doi.org/10.1016/j.jmathb.2020.100824

English, L. D., \& Watson, J. M. (2016). Development of probabilistic understanding in fourth grade. Journal for Research in Mathematics Education, 47(1), 28-62. https://doi.org/ 10.5951/jresematheduc.47.1.0028

Haciomeroglu, E. S. (2016). Object-spatial visualization and verbal cognitive styles, and their relation to cognitive abilities and mathematical performance. Kuram ve Uygulamada Egitim Bilimleri, 16(3), 987-1003. https://doi.org/10.12738/estp.2016.3.0429

Haciomeroglu, E. S., \& LaVenia, M. (2017). Object-spatial imagery and verbal cognitive styles in high school students. Perceptual and Motor Skills, 124(3), 689702. https://doi.org/10.1177/0031512517698555

Kuntze, S., Aizikovitsh-Udi, E., \& Clarke, D. (2017). Hybrid task design: connecting learning opportunities related to critical thinking and statistical thinking. ZDM - Mathematics Education, 49(6), 923-935. https://doi.org/10.1007/s11858-017-0874-4

Lyn D. English, \& Jane M. Watson. (2016). Development of Probabilistic Understanding in Fourth Grade. Journal for Research in Mathematics Education, 47(1), 28. https://doi.org/10.5951/jresematheduc.47.1.0028

Miles, M. B., Huberman, A. M., \& Saldana, J. (2014). Qualitative Data Analysis: A Methods Sourcebook (Third Edit). SAGE Publications, Inc.

Pitta-Pantazi, D., \& Christou, C. (2009). Cognitive styles, dynamic geometry and measurement performance. Educational Studies in Mathematics, 70(1), 526. https://doi.org/10.1007/s10649-008-9139-z

Stylianides, G. J., \& Stylianides, A. J. (2009). Facilitating the Transition from Empirical Arguments to Proof. Journal for Research in Mathematics Education, 40(3), 314352. https://doi.org/10.2307/40539339

Zahner, D., \& Corter, J. E. (2010). The process of probability problem solving: Use of external visual representations. Mathematical Thinking and Learning. https://doi.org/10.1080/10986061003654240 